\title{
Petrophysical Analysis of 'Bright' Field, Onshore Niger Delta
}

\author{
Advances in Earth and Environmental Science
}

Research Article

Abe Sunday James

Department of Applied Geophysics, Federal University of

Technology Akure, Ondo State, Nigeria

\author{
* Correspondence authors \\ Abe Sunday James \\ Department of Applied Geophysics \\ Federal University of Technology Akure \\ Ondo State \\ Nigeria
}

Submitted : 12 Oct 2021 ; Published : 30 Oct 2021

\begin{abstract}
Petrophysical analysis is key to the success of any oil exploration and exploitation work and this task requires evaluation of the reservoir parameters in order to enhance accurate estimation of the volume of oil in place. This research work involves the use of suite of well logs from 4-wells to carry out the petrophysical analysis of 'Bright' Field Niger Delta. The approach used includes lithology identification, reservoir delineation and estimation of reservoir parameters. Two sand bodies were mapped across the entire field showing their geometry and lateral continuity, gamma ray and resistivity logs were used to delineate the reservoirs prior to correlation and relevant equations were used to estimate the reservoir parameters. The result of the petrophysical analysis showed variations in the reservoir parameters within the two correlated sand bodies with high hydrocabon saturation in sand 1 well 1 while the remaining wells within the correlated wells are water bearing. The porosity values range from 0.19 to 0.32 , volume of shale from 0.15 to 0.40 , water saturation from 0.20 to 0.92 for the sand bodies.
\end{abstract}

Keywords: Lithology. Porosity, Permeability, Reservoir

\section{Introduction}

Understanding of lithology, pore fluid and accurate determination of reservoir parameters are fundamental to any petrophysical analysis [1]. Determining lithology and pore fluid are key for effective exploration and production of hydrocarbon. However, accurate prediction of lithology and pore fluid is, and will continue to be, a key challenge for hydrocarbon exploration and development [2]. The accurate determination of lithology and pore fluid aids in the accurate determination of porosity, saturation, and permeability. The economic viability of a hydrocarbon field is also reliant on the quality and accuracy of lithology and pore fluid [3]. The growing difficulty in convention (reservoir that uses the natural pressure gradient for hydrocarbon extraction) and unconventional (reservoir that requires special recovery operations outside the conventional operating practices) reservoir has made precise lithology and pore fluid prediction very essential [3]. The accurate determination of lithology and pore fluid also aid petroleum engineering decisions making.

Lithology and pore fluid can be unambiguously determined using core samples obtained from underground formation. Core sample analysis for lithology and pore fluid prediction is expensive and usually involves vast amount of time and effort to obtain reliable information [4]. Hence, this method cannot be applied to all drilled wells in a field. Also, different geoscientists may obtain inconsistent results based on their own observation and analysis [5,6]. Cuttings obtained from drilling operations can also be used to determine lithology and pore fluid. The main disadvantage of using cuttings from drilling operation to determine lithology and pore fluid is that the retrieval depth of the cuttings are usually unknown and the samples are generally not large enough for precise and reliable determination of lithology and pore fluid [6]. Considering the limitations mentioned for other methodologies, there has been a growing interest in determining lithology and pore fluid using well log data which is cheaper, more reliable, and economical compared to the other methods stated above. This will enhance accurate estimate of the hydrocarbon pore volume. Well logging also offers the benefit of covering the entire geological formation of interest coupled with providing general and excellent details of the underground formation [6]. Brigaud et al. (1990) observed that well logs offers a better representation of in-situ conditions in a lithological unit than laboratory measurements mainly because well logs sample finite volume of rock around the well and delivers uninterrupted record with depth instead of sampling of discrete point [7]. This research work therefore involves the use wells to carry out the petrophysical analysis of 'Bright' field, Niger Delta.

\section{Location and Geology of the Study Area}

The field is located within the onshore part of Niger delta. (Figure 1). The base map showed the location of the four wells The field belongs to an active oil producing company in Nigeria. It covers an area extent of about $51,187 \mathrm{~km}^{2}$ and it lies Adv Earth \& Env Sci; $2021 \quad$ www.unisciencepub.com Volume 2 | Issue 4 
within longitude $8.0^{\circ} \mathrm{E}$ to $8.3^{\circ} \mathrm{E}$ and latitude $4.0^{\circ} \mathrm{N}$ to $4.3^{\circ} \mathrm{N}$.

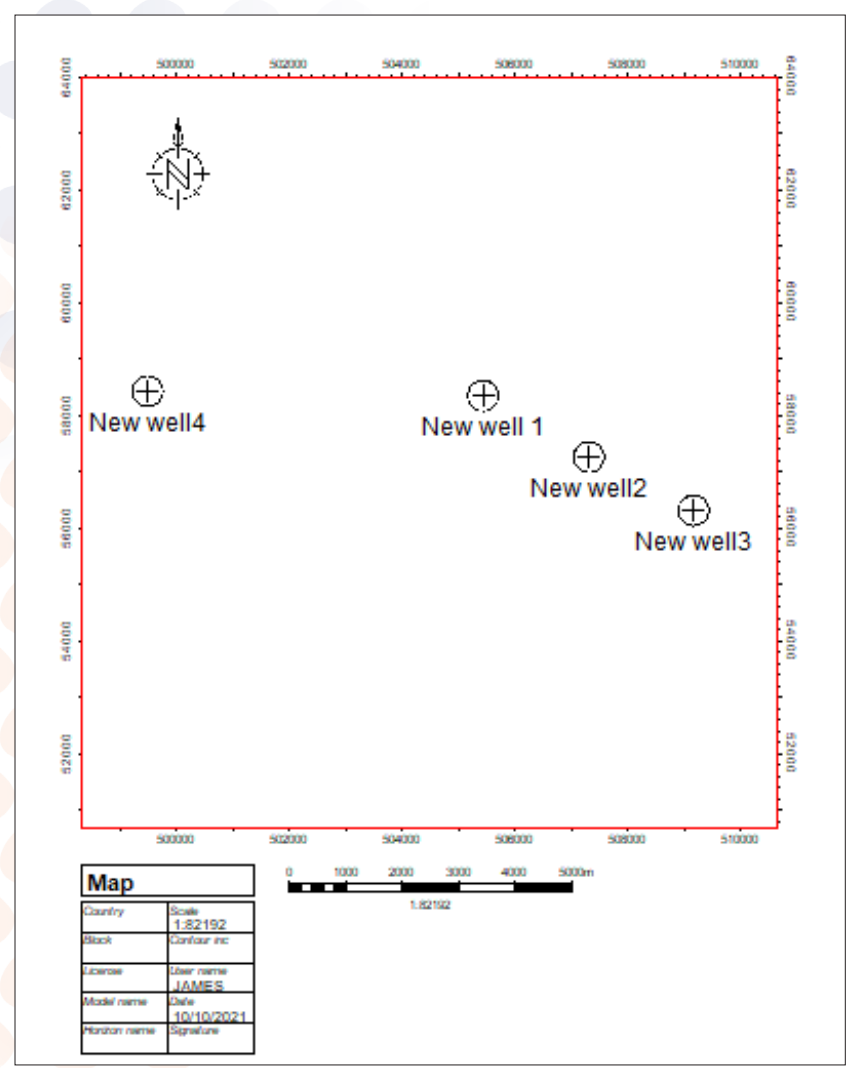

Figure 1: Base Map of the Study Area showing Well Locations

Niger Delta is a prolific hydrocarbon belt in the world. The formation of Niger Delta basin was initiated in the early Tertiary time. The Niger Delta is situated in the Gulf of Guinea and extends throughout the Niger Delta province. From the Eocene to the present, the Delta has prograded Southwest ward, forming depobelts that represent the most active portion of the Delta at each stage of its development [8]. Three lithostratigraphic units have been recognized in the subsurface of the Niger Delta $[9,10]$. These are from the oldest to the youngest, the Akata, Agbada and Benin Formations (Figure 2). The Akata Formation (Eocene-Recent) is a marine sedimentary succession that is laid in front of the advancing delta and ranges from $1,968 \mathrm{ft}$ to $19,680 \mathrm{ft}(600-6,000 \mathrm{~m})$ in thickness. It consists of mainly uniform undercompacted shales with lenses of sandstone of abnormally high pressure at the top [10]. The shales are rich in both planktonic and benthonic foraminifera and were deposited in shallow to deep marine environment [9]. The Agbada Formation (Eocene-Recent) is characterized by paralic interbedded sandstone and shale with a thickness of over $3,049 \mathrm{~m}$. The top of Agbada Formation is defined as the first occurrence of shale with marine fauna that coincides with the base of the continental-transitional lithofacies. The base is a significant sandstone body that coincides with the top of the Akata Formation [9]. Some shales of the Agbada Formation were thought to be the source rocks, however; Ejedawe et al., (1984) deduced that the main source rocks of the Niger Delta are the shales of the Akata Formation [11]. The Benin Formation is the youngest lithostratigraphic unit in the Niger Delta. It is Miocene - Recent in age with a minimum thickness of more than $6,000 \mathrm{ft}(1,829 \mathrm{~m})$ and made up of continental sands and sandstones $(>90 \%)$ with few shale intercalations. The sands and sandstones are coarse grained, subangular to well rounded and are very poorly sorted.

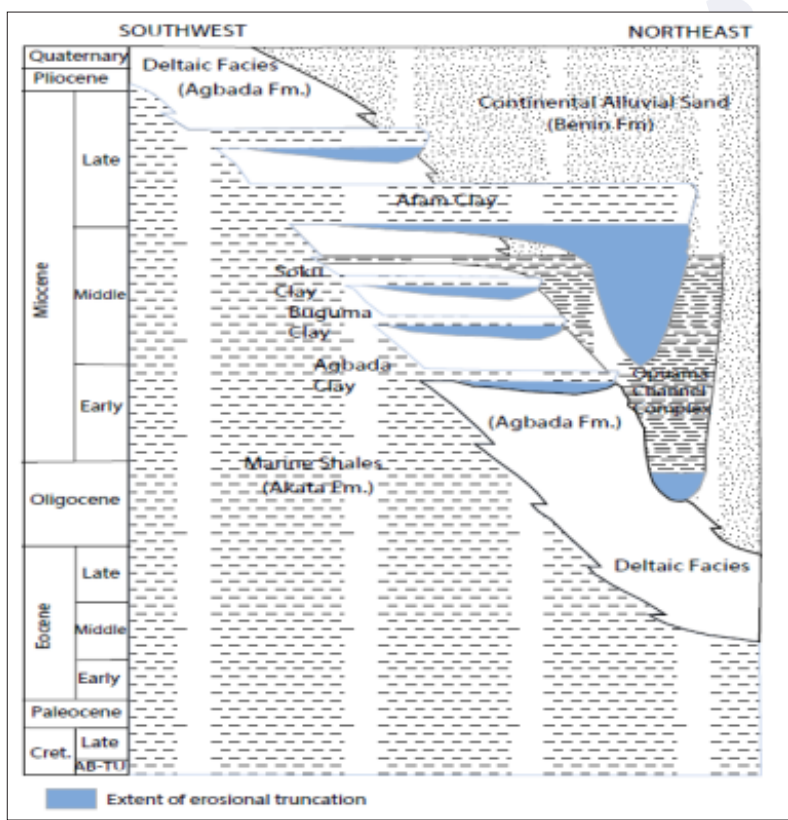

Figure 2: Stratigraphic column showing the three formations of the Niger Delta. Modified from Shannon and Naylor (1989) and Doust and Omatsola (1990) $[8,12]$.

\section{Methodology}

The method used in analysing the study area petrophysically includes:

\section{Data Import}

The sequence of data import begins with the well heads and logs. The well heads file, contained the well name, surface location of the wells (2D-XY coordinate system), Kelly bushing $(\mathrm{Kb})$, the top depth, bottom depth and the measured depth (MD). These enabled the display of well position on the base map. The logs were then imported and attached to the well head.

\section{Lithologic Correlation}

The gamma ray log was used to identify similar features at different localities. That is, it involved the correlation of equivalent strata from one well to the next in order to determine similarity or equivalence of lithology in two or more wells. This was achieved using similarity in gamma ray $\log$ signatures in the different wells. The log measures natural radioactivity in formations. Shale- free sandstones have low concentration of radioactive materials, thus low amplitude of gamma ray log indicated the presence of sand, while a high amplitude of the gamma ray log, showed the presence of shale. This enabled the zoning of the study area into alternating sand and shale sequence.

\section{Reservoir Correlation}

Potential reservoirs across the wells, which correspond to equal depths, were determined using the gamma ray log 
and resistivity logs. This is with a view to calculate the petrophysical parameters across wells in order to make useful quantitative deductions.

The various reservoir parameters were estimated as stated below:

Volume of Shale (Vsh)

The gamma ray log was used to calculate the volume of shale in the reservoirs. The first step used to determine the volume of shale from a gamma ray log was the calculation of the gamma ray index using the equation below:

$\mathrm{IGR}=(\mathrm{GRlog}-\mathrm{GRmin}) /(\mathrm{GRmax}-\mathrm{GRmin})$

where: IGR = Gamma ray index;

GRlog $=$ Gamma ray reading of the formation.

GRmin = Minimum gamma ray (clean sand); and

GRmax $=$ Maximum gamma ray (shale).

All these values were read off within a particular reservoir. Having obtained the gamma ray index, volume of shale was then calculated using the Dresser Atlas formula below:

$\left.\mathbf{V s h}=\mathbf{0 . 0 8 3}{ }^{\left(2\left(3.7 \times{ }^{I}\right.\right.} G^{)}-1.0\right)($ Tertiary unconsolidated sand)

\section{Porosity ( $\phi)$}

Porosity is defined as the percentage of voids to the total volume of rock. The formation density log was used to determine formation porosity. The formation porosity was determined by substituting the bulk density readings obtained from the density $\log$ within the reservoirs into the equation below

$\boldsymbol{\Phi D}=\left(\rho_{\mathrm{ma}}-\rho_{\mathrm{b}}\right) /\left(\rho_{\mathrm{ma}}-\rho_{\mathrm{f}}\right)$

where, $\rho_{\mathrm{ma}}=2.65 \mathrm{gm} / \mathrm{cc}$ (sandstone)

$\rho_{\mathrm{f}}=1.0 \mathrm{gm} / \mathrm{cc}$ (fluid density).

$\rho_{\mathrm{b}}=$ formation bulk density

\section{Formation Factor (F)}

The formation factor was determined from the Archie equation $\mathrm{F}=\mathrm{a} / \boldsymbol{\Phi}^{\mathrm{m}}$

where: $\boldsymbol{\Phi}=$ Porosity

$\mathrm{a}=$ constant $(0.62)$; and

$\mathrm{m}=$ cementation exponent ( 2 for sands).

\section{Estimation of Formation water Resistivity $\left(\mathbb{R}_{w}\right)$}

Using the Archie's equation that relates the formation factor (F) to the resistivity of a formation at $100 \%$ water saturation $\left(R_{0}\right)$ and the resistivity of formation water $\left(R_{w}\right)$, the resistivity of the formation water was estimated as:

$$
\mathrm{R}_{\mathrm{w}}=\frac{\mathrm{R}_{0}}{\mathrm{~F}}
$$

\section{Estimation of water saturation}

Determination of the water saturation for the uninvaded zone was achieved using the Archie's equation given below:

$$
\mathrm{S}^{2} \mathrm{w}=\mathrm{F} \times \mathrm{R}_{\mathrm{w}}
$$

$$
\mathrm{R}_{\mathrm{t}}
$$

where,

$\mathrm{S}_{\mathrm{w}}=$ water saturation of the uninvaded zone
$R_{0}=$ resistivity of formation at $100 \%$ water saturation; and

$\mathrm{R}_{\mathrm{t}}=$ true formation resistivity

$\mathrm{S}_{\mathrm{w}}=$ water saturation of the uninvaded zone

\section{Permeability (k)}

It is controlled by the size of the connecting passages (pore throats or capillaries) between pores. It is measured in Darcies or millidarcies.

$\mathrm{K}=250 \times \boldsymbol{\phi}^{3} /$ Swirr [13].

where,

$\mathrm{K}=$ Permeability; and

$\Phi=$ Porosity

Swirr $=$ Irreducible water saturation.

\section{Hydrocarbon Saturation $\left(\mathrm{S}_{\mathrm{h}}\right)$}

This is the percentage of pore volume in a formation occupied by hydrocarbons.

i.e $\mathrm{S}_{\mathrm{h}}=\left(100-\mathrm{S}_{\mathrm{w}}\right) \%$

where,

$\mathrm{S}_{\mathrm{h}}=$ Hydrocarbon saturation

$\mathrm{S}_{\mathrm{w}}=$ Water saturation

\section{Result and Discussion}

The general depth window of interest ranged from $2490 \mathrm{~m}$ to $3030 \mathrm{~m}$ from where the two Sands 1 and 2 were mapped. The distance between Wells 1, 2 and 3 are about $2 \mathrm{~km}$, while the distance between Wells 4 and 1 is about $5 \mathrm{~km}$. Figure 3 is the well correlation panel showing the top and base of Sand 1; it shows that the sand body has varying proportion of sand and shale across the four wells. The thickness also varies across the wells, within a depth interval of $2510 \mathrm{~m}-2547 \mathrm{~m}$ in well 1 , $2515 \mathrm{~m}-2535 \mathrm{~m}$ in well 2,2490m - 2530m in well 3 and $2502 \mathrm{~m}$ $-2530 \mathrm{~m}$ in Well 4. It is thickest in Well 3 and thinnest in Well 2 . This variation in thicknesses may probably be as a result of the tectonic activities that had taken place in the field.

In Well 1, the resistivity log reads a high value within Sand 1 showing that it is hydrocarbon bearing, while the resistivity values are low for thesame Sand 1 in Wells 2, 3 and 4. There was a thick column of shale above and below it which would enhance the sealing potential for the hydrocarbon within it. Sand 2 also depicts variation in thickness across the entire four wells as shown in Figure 4. The sand body is cleanest in Well 4, owing to the high proportion of sand-shale within it compared to others wells. The log readings are high across the wells, showing that they are all hydrocarbon bearing and there are also thick column of shale overlying and underlying them which serves as good seal. It is thickest in Well 4 and thinnest in Well 1. Sand 2 in Well 1 is within a depth interval of $2950 \mathrm{~m}$ - 2965m, 2995m - 3025m in Well 2, 2940m - 2980m in Well 3 and $2930 \mathrm{~m}-2982 \mathrm{~m}$ in Well 4.

Adv Earth \& Env Sci; $2021 \quad$ www.unisciencepub.com 


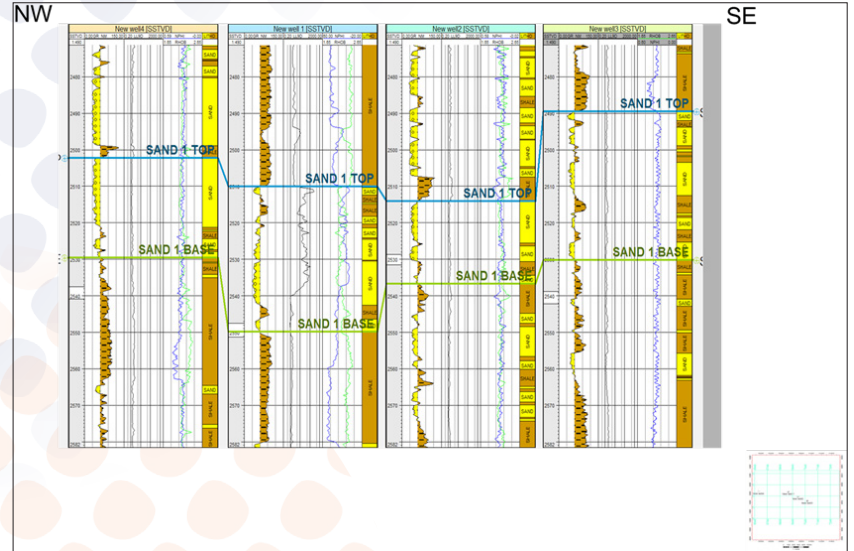

Figure 3: Well Correlation Panel showing the Top and Base of Sand 1

The petrophysical parameters estimated from Sand 1 is shown in Table 1 . The gross thickness of the sand body range 17.76 to 40.84 , the net thickness which is the amount of sand within it vary from $14.71 \mathrm{~m}$ to $27.83 \mathrm{~m}$, the net pay is $22.59 \mathrm{~m}$ in Well 1 showing that it is a reservoir, while it is $0 \mathrm{~m}$ in other wells. The volume of shale range from 0.02 to 0.35 , which shows that we have low amount of shale within it and this is corroborated by the high values of net to gross that was estimated within Sand 1. Wireline logs were used to identify hydrocarbon bearing zone, calculate hydrocarbon volume, determine porosity and permeability, identify lithology, etc. The permeability range between $952 \mathrm{mD}$ to $3050 \mathrm{mD}$ suggesting that the pore spaces are inter-connected to enhance fluid flow within it. Porosity values range from 0.19 to 0.31 , which substantially high to allow accumulation of hydrocarbon within the sand body.

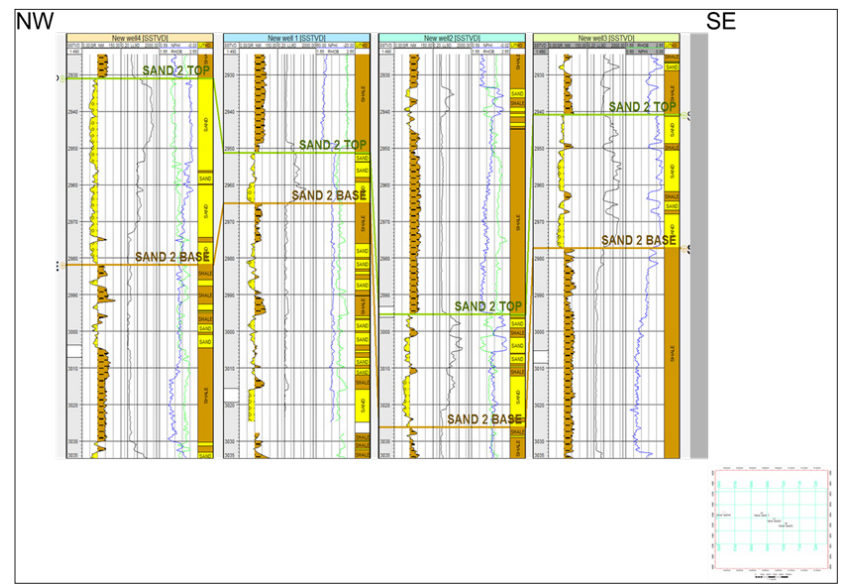

Figure 4: Well Correlation Panel showing the Top and Base of Sand 2

The permeability values are excellent and these values showed that sand 1 is a good reservoir. The reservoir parameters estimated for Sand 2 is shown in Table 4.2 and the gross thickness vary from $13.27 \mathrm{~m}$ to $73.19 \mathrm{~m}$ which are values that are sufficient for accumulation of hydrocarbon in commercial quantity. The net pay, which is the amount of sand within Sand 2 range from $11.77 \mathrm{~m}$ to $60.64 \mathrm{~m}$, the net pay has a range of $5.44 \mathrm{~m}$ to $43.36 \mathrm{~m}$ and these initial values gave high net to gross range for Sand 2 to be from 0.78 to 0.89 .

The porosity and permeability values are from 0.20 to 0.32 and $1000 \mathrm{mD}$ and $3122 \mathrm{mD}$ respectively. Due to the high net to gross values, we have corresponding low volume of shale values ranging from 0.09 to 0.40 . Sand 2 is hydrocarbon bearing in all the wells because of the low water saturation and high hydrocarbon saturation values. The porosity values can be rated very good to excellent and the permeability values as excellent $[14,15]$.

The petrophysical parameters estimated for both Sands 1 and 2 were plotted on bar charts as shown in Figures 5,6 and 7. Figure 5 shows the plot of the gross, net and net pay thicknesses for the two mapped sand bodies across the four wells. The gross thickness is highest in Sand 2 Well 4 and lowest in Sand 2 Well 1 .

Figure 6 shows the variation in permeability for the two sands. In Well 4 the permeability values for the sands are very close and also in Well 1, but the values are far apart in Wells 2 and 3 . This could be due to the presence of shale that reduce the pore interconnectivity in Sand 1 Well 2 and Sand 2 Well 3. Generally, the permeability value is highest in Well 2 sand 2 and lowest in Well 2 sand 1.

Figure 7 is the plot of the net to gross, porosity, volume of shale and water saturation for the four wells. Net to gross is highest in Sand 2 Well 1and lowest in Sand 1 Well 3. The values of the net to gross are almost thesame in Sand 2 Wells 3 and 4. The porosity value is highest in Sand 2 Well 2 and lowest in Sand 1 Well 2.

The volume of shale also varied across the wells for the two sands with the highest value in Sand 2 Well 4 and lowest in Sand 1 Well 4. Water saturation values are generally high in Sand 1 and low in Sand 2. It is lowest in Sand 2 Well 4 and highest in Sand 1 Well 3. This implies that it is only Well 1 that is hydrocarbon bearing in Sand 1, while Sand 2 contains hydrocarbon across the four wells since a reduction in the water saturation value will give a corresponding high hydrocarbon saturation value. 


\begin{tabular}{|l|l|l|l|l|l|l|l|l|l|}
\hline SAND 1 & Gross $(\mathrm{m})$ & Net $(\mathrm{m})$ & Net Pay $(\mathrm{m})$ & $\mathrm{N} / \mathrm{G}$ & $\varnothing($ frac. $)$ & $\mathrm{K}(\mathrm{mD})$ & $\mathrm{V}_{\mathrm{sh}}$ & $\mathrm{S}_{\mathrm{w}}$ & $\mathrm{S}_{\mathrm{h}}$ \\
\hline WELL 1 & 38.65 & 27.83 & 22.59 & 0.72 & 0.25 & 1318 & 0.07 & 0.24 & 0.76 \\
\hline WELL 2 & 17.76 & 14.71 & 0.00 & 0.83 & 0.19 & 952 & 0.35 & 0.85 & 0.15 \\
\hline WELL 3 & 40.84 & 25.43 & 0.00 & 0.62 & 0.31 & 3050 & 0.32 & 0.92 & 0.08 \\
\hline WELL 4 & 27.57 & 24.32 & 0.00 & 0.88 & 0.28 & 2900 & 0.02 & 0.82 & 0.18 \\
\hline
\end{tabular}

Table 1: Petrophysical Parameters for Sand 1

\begin{tabular}{|l|l|l|l|l|l|l|l|l|l|}
\hline SAND 2 & Gross $(\mathrm{m})$ & Net $(\mathrm{m})$ & Net Pay $(\mathrm{m})$ & $\mathrm{N} / \mathrm{G}$ & $\varnothing($ frac.) & $\mathrm{K}(\mathrm{mD})$ & $\mathrm{V}_{\mathrm{sh}}$ & $\mathrm{S}_{\mathrm{w}}$ & $\mathrm{S}_{\mathrm{h}}$ \\
\hline WELL 1 & 13.27 & 11.77 & 5.44 & 0.89 & 0.23 & 1452 & 0.09 & 0.31 & 0.69 \\
\hline WELL 2 & 30.63 & 23.90 & 20.59 & 0.78 & 0.32 & 3122 & 0.15 & 0.38 & 0.62 \\
\hline WELL 3 & 35.81 & 30.79 & 30.79 & 0.86 & 0.20 & 1000 & 0.21 & 0.43 & 0.57 \\
\hline WELL 3 & 73.19 & 60.64 & 43.36 & 0.86 & 0.25 & 2883 & 0.40 & 0.20 & 0.80 \\
\hline
\end{tabular}

Table 2: Petrophysical Parameters for Sand 2

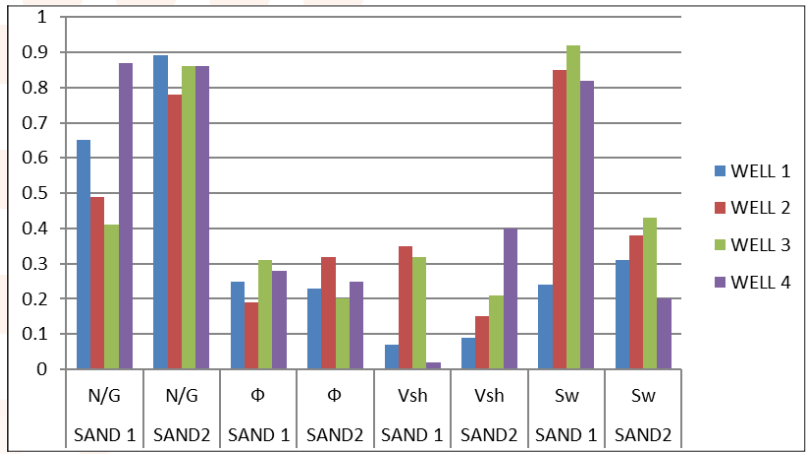

Figure 5: Bar Chart Showing Gross, Net and Net Pay Thicknesses for the 4-Wells

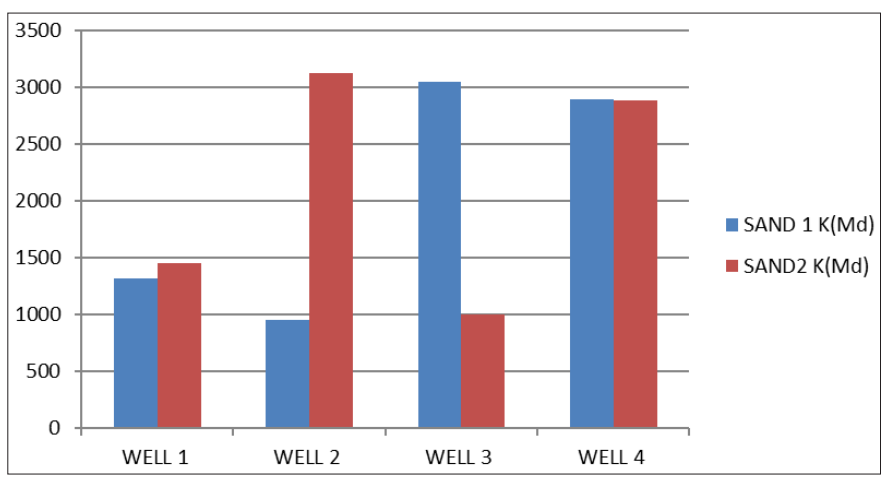

Figure 6: Bar Chart Showing Permeability Variations for Sands 1 and 2, across Wells 1- 4

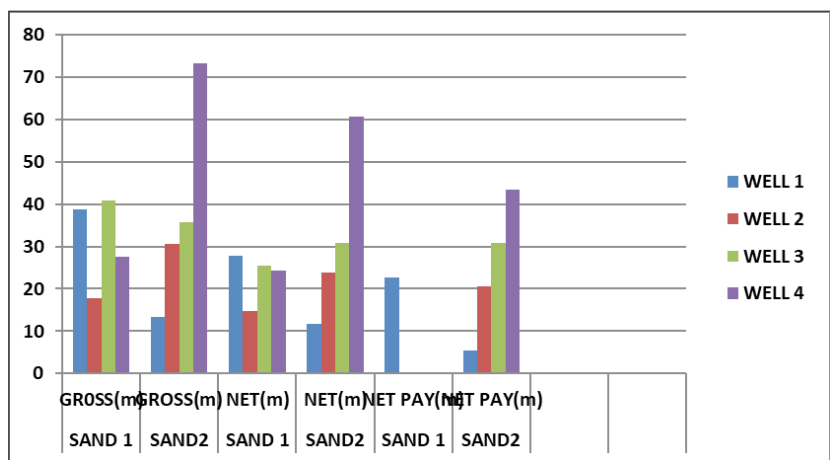

Figure 7: Bar Chart Showing N/G, $\Phi$, Vsh and Sw Variations for Wells 1- 4

\section{Conclusion}

The petrophysical analysis carried out revealed the lateral continuity of the two mapped sands across the existing four well locations and their geometry, together with their hydrocarbon potentials. Sands 1 and 2 have thicknesses that ranged from $13.27 \mathrm{~m}$ to $73.19 \mathrm{~m}$ across the wells. Sand 1 is thickest in Well 3 and thinnest in Well 2, Sand 2 is thickest in Well 4 and thinnest in Well $1[16,17]$.

The reservoir parameters estimated from the two sand bodies, which include the gross thickness, net thickness, net pay, net to gross, porosity, permeability, volume of shale, water saturation and hydrocarbon saturation all gave information that served as input into the processes for the characterization of Sands 1 and 2. In Sand 1, Well 3 has the highest gross thickness of $40.84 \mathrm{~m}$ while well 1 has the highest net thickness of $27.83 \mathrm{~m}$. Only Well 1 in sand 1 is hydrocarbon-bearing because the net pay in Wells 2, 3 and 4 are zero while the net pay in Well 1 is $22.59 \mathrm{~m}$. Net-to-gross values in sand 1 ranged between 0.62 to 0.88 adjudged favourable for a good reservoir. The permeability values were excellent because they are averagely above $1000 \mathrm{mD}$. Since the net to gross values were high, there is a considerable reduction in the volume of shale values within the sand body. Water saturation value is very low in Well 1 with a value of 0.24 because it contained hydrocarbon with hydrocarbon saturation of $76 \%$ and above in the other wells. In 
Sand 2, Well 4 had the highest gross, net and net pay thickness. All the wells penetrating Sand 2 contained hydrocarbon from the reading of the deep resistivity log. The net to gross values ranged from 0.78 to 0.89 , while the porosity values ranged from 0.20 to 0.32 and are deemed very good to excellent. The permeability was excellent and the volume of shale values ranged from 0.09 to 0.40 in all the wells. The water saturation ranged from $20 \%$ to $43 \%$ with a corresponding hydrocarbon saturation ranging from $57 \%$ to $80 \%$.

\section{References}

1. Abe SJ, Olowokere MT, Enikanselu PA (2021) Geostatistical Modelling of Reservoir Quality Over 'Bright' Field, Niger Delta. Journal of Geology and Geophysics.

2. Kupecz JA, Gluyas J, Bloch S (1997) Reservoir Quality Prediction in Sandstones and Carbonates: An Overview.

3. Hami-Eddine K, Klein P, Loic R, Ribet B, Grout M (2015) A new technique for lithology and fluid content prediction from prestack data: An application to carbonate reservoir.

4. Chang H, Kopaska-Merkel D, Chen (2002) Identification of lithofacies using Kohonen Self - Organizing Maps. Computers and Geosciences. 28: 223-229.

5. Akinyokun OC, Enikanselu PA, Adeyemo AB, Adesida A (2009) Well log interpretation model for the determination of lithology and fluid content contents. The Pacific Journal of Science and Technology 10: 507-517.

6. Serra O, Abbott HT (1982) The contribution of logging data to sedimentology and stratigraphy and stratigraphy. Society of Petroleum Engineers Journal 22: 117-131.

7. Brigaud F, Chapman DS, Le Douaran S (1990) Estimating thermal conductivity in Sedimentary Basin using lithological data and geophysical well logs: $A A P G$ Bulleting. 74: 1459-1477.

8. Doust H, Omatsola E (1990) Niger Delta, in, Edwards, J. D., and Santogrossi, P.A., eds., Divergent/passive Margin Basins, AAPG Memoir 48: Tulsa, American Association of Petroleum Geologists 239-248.

9. Short KC, Stauble J (1967) Outline geology of the Niger Delta. AAPG Bull 5: 761-779.

10. 10. Avbovbo AA (1978) Tertiary lithostratigraphy of Niger Delta: American Association of Petroleum Geologists Bulletin 62: 295-300.

11. Ejedawe JE, Coker SJL, Lambert-Aikhionbare DO, Alofe KB, Adoh FO (1984) Evolution of oil generative window and oil and gas occurrence in Tertiary Niger Delta Basin: American Association of Petroleum Geologists 68: 17441751.

12. Shannon PM, Naylor N (1989) Petroleum Basin Studies: London, Graham and Trotman Limited 153-169.

13. Tixier MP (1949) Evaluation of Permeability from Electric-Log Resistivity Gradients. Oil and Gas J.

14. Etu-Efeotor JO (1997) Fundamentals of petroleum geology. Paragraphic publications, Port Harcourt, Nigeria 135.

15. Adeoti L, Njoku O, Olawale O, Fatoba J, Musa B (2014) Static Reservoir Modelling using Well Log and 3-D Seismic Data in a KN Field, Offshore Niger Delta, Nigeria: International Journal of Geoscience 5: 99-106.
16. Schlumberger (1989) Log Interpretation, Principles and Application. Schlumberger Educational Services, Texas 2-1.

17. Schlumberger Oilfield Services presentation at the IHS CERA Week conference in February 2009.
Copyright: (C)2021 Abe Sunday James. This is an open-access article distributed under the terms of the Creative Commons Attribution License, which permits unrestricted use, distribution, and reproduction in anymedium, provided the original author and source are credited. 